\title{
Resolving Stakeholder Challenges in the Higher Education System
}

\author{
Godson A. Tetteh, PhD, ASQ CSSBB
}

Email: gtetteh@gimpa.edu.gh

Ghana Institute of Management and Public Administration

\begin{abstract}
Purpose: The purpose of this paper is to study how to resolve conflicts among major the stakeholders using the Kano et al. (1984) model so as to improve the quality of higher education (HE).

Design/Methodology/Approach: The study presented in this paper was part of an action research study. The empirical material was collected by various methods (interviews and survey) in private and public higher education institutions in Accra, Ghana. The respondents included academic leaders, administrators, teachers and students.

Findings: The study shows that incorporating a view of major stakeholder expectations in a Kano et al. (1984) model could help resolve conflicts, and prioritize the stakeholder needs.

Practical Implications: The outcome of this paper could aid higher education administrators (HEAs) improve the existing planning processes and help resolve needs (critical to quality-CTQ) of other major stakeholders with some social benefits.

Originality/Value: This paper expounds on applying the Kano et al. (1984) model based on major stakeholder expectations in the higher education system to achieve quality. While a number of papers have been published on the applications of Kano et al. (1984) model, scarcely have one used the model to resolve conflicts among major the stakeholders in the HE system. This approach appears to overcome a gap, identified in an earlier research.
\end{abstract}

Keywords: higher education quality, kano model, stakeholder expectations, stakeholder conflict resolution

Paper type: Research paper 


\section{Introduction}

The author conducted an exit interview with a former rector of a higher education institution (HEI) about some management challenges during his tenure of office. The rector is the Chief Executive Officer of a HEI and a member of the council of governors. The exit interview focused on the belief that stakeholders of HEIs held diverse needs or expectations on quality higher education (Pham and Starkey, 2016). Scholars have argued about the definition of quality in terms of the HEIs (Sunder, 2016; UNESCO, 2014). And higher education administrators (HEAs) face a daunting task with persistent demands for rigorous academic quality standards and the need to meet all the needs or expectations of the major stakeholders. The stakeholder (or customer) satisfaction from the conceptual framework in quality management is the leading criterion for determining the quality of the product/service offered (Ganguli and Roy, 2011; Pizam et al. 2016 and Vavra, 1997, 2002). Thus, the HEA is accountable to the major stakeholders to achieve quality.

Previous research shows that as the number of stakeholders' increase, there is a likelihood of disagreement on the definition of quality of education, and miscommunication of expectations and priorities (Kreps, 1990; Finch, 1994; Hatami et al. 2016). An effective HEA must build consensus with the major stakeholders to improve the quality of higher education. Nevertheless, difficulties in changing the organizational culture and the absence of tools create substantial obstacles in improving the quality of higher education (Luxford et al. 2011). To overcome these difficulties, one needs a tool that supports an understanding of the major stakeholder needs and expectations (Mazur, 2003).

The exit interview with the former rector revealed that HEAs experience challenges in the process of transforming their institutions, with opposing forces and major stakeholders having competing interests (Mabokela, 2002). What are the needs and preferences of the major stakeholders within the HEIs? What tools are available to address these stakeholder needs and preferences? What are some of the challenges in implementing some of these tools? We decided to use an action research to answer these questions.

\section{Literature Review}

Identification of Stakeholders in the HE System

Freeman (1984) had defined a stakeholder as "any group or individual who can affect or is affected by the achievement of an institution's purpose". From this definition a stakeholder can be a single person or a group, who can influence, or is influenced by, the achievement of the institutions' goals and objectives. Kumar et al. (2016) had suggested an approach to identify and classify stakeholders in order to recognize the major stakeholders who affect, or are affected during the achievement of organizational objectives. Kumar et al. (2016), proposed four categories of classes of stakeholders: economic, social, environmental and regulatory. For a firm, Friedman and Miles (2006) proposed the major stakeholders as: customers, employees, local communities, suppliers and distributors, shareholders, the media, the public in general, future generations, past generations, academics, competitors, non-governmental organizations, activists, trade unions or trade associations, financiers, government, regulators and policy makers. According to Asiyai (2015), the HE major stakeholders are made up of internal stakeholders such as HE governing council, HE administrators, students, teachers and other staff members. External stakeholders include nongovernmental organizations, community based organizations, government oversight commissions, 
parents, employers of labor, trade unions, alumni association, industries/firms, the HE competitors, development agencies both local and international, and the society as a whole.

\section{HE Stakeholder Expectations \\ HE Governing Council}

National governments that own public HEIs are represented by a governing council. The HE governing council performs numerous roles including defining strategic vision, policy formulation and monitoring to ensure continuous improvement in the quality of higher education (Asiyai, 2015). The governing council in the private HEIs perform a similar role. Usman (2014), posit that an effective policy making decision requires an enlightened governing council that has a broad view of the impact of higher education on the society, and is cognizant of the strategic direction in terms of quality.

The fundamental purpose of HE policymakers and their expectation is to develop the knowledge and skills students need for professional, technical, and managerial positions. Brint and Clofter (2016), posit that higher education has expanded from an elite to a mass system, and policymakers have taken an interest as well in whether higher education opportunities are accessible to all and fairly distributed. Notwithstanding, Goldin and Katz (2008) had argued that higher education accessibility is an important measure of social mobility to bring greater equality to society. Policymakers have also focused on the volume and quality of higher education's production of basic and applied researchers, that will become the next generation of scholars and scientists (see, Cole, 2009).

Finally, policymakers would want to expand higher education to ensure human capital development to meet the changing occupational needs of an increasingly knowledge-based society. Thus Brint and Clofter (2016), suggest the following questions for assessing the quality of higher education to meet stakeholders' expectations: Are students being prepared adequately for the labor market? Is the system accessible to students from all backgrounds? How large are the gaps in success between students from different backgrounds? Is research productivity high and is it contributing to human well-being? Are HEIs producing well-prepared graduate students? Are the new business methods contributing to greater quality and effectiveness in the allocation of resources? Has the emphasis on interdisciplinary collaboration led to a greater capacity to tackle key national problems? How much are students learning? To what extent are the new instructional practices and technologies contributing to student learning?

\section{Higher Education Administrator (HEA)}

Most HEAs focus on global ranking and accreditation institutions to determine the quality of higher education. According to (Sunder 2016), the expectations of HEAs include: increase in enrollment; global ranking; number of research papers published per department; quality of research; HEI maintenance and infrastructure metrics; standard of teaching; Student's absenteeism; and effectiveness of accreditation process among others.

\section{Students}

HE institutions' vision and mission statements focus on the students to provide quality education and create an enabling environment for the students to succeed. Several studies have defined students as the primary customers in the HEIs (Gruber et al., 2010; Mergen et al., 2000; Wallace, 
1999), and teachers, administrative staff and other employees as a category of customers (Kanji et al., 1999). In one study, Sharabi (2013) categorizes the major stakeholders of HEIs into three tiers - students (customer tier), other employees (boundary tier) and higher education administrators (coordination tier).

The expectation of every student in a higher education institution is to graduate and obtain a decent job to improve his or her earnings inconsonance with the UNESCO's Global Education 2030 Agenda through Sustainable Development Goal 4 (UN Sustainable Development Goals, 2016). Thus, the teaching and learning processes, and the outcomes must promote problem-solving and creative thinking, understanding and respect for human rights, inclusion and equity; all of which are essential to the realization of peace, responsible citizenship and sustainable development. Recent research has identified the expectations of students as: access to e-library or turnaround time for issuing books in the library; turnaround time for admission process; computer systems downtime; number of students placed at corporate jobs; salary range of alumni; residential facilities at hostel rooms and others (Sunder, 2016).

\section{Conflicts in HE Stakeholder Needs or Expectations}

Kotler posits that quality science, just like marketing science establishes the need to clearly define and understand the needs of the customer or stakeholder as a prerequisite for any management philosophy (Kotler, 2012). A variety of literature has been published on the definition of quality higher education (HE): as a philosophical concept and elusive (Elassy, 2015); as fitness for purpose (Woodhouse, 2006); as a transformation and adding of value to the stakeholder (Chong, 2014); as a context-relative term such as teaching and learning (Elassy, 2015); and as a stakeholder-relative concept including students, academics, employers, non-academic staff, government, funding agencies, accreditors, and assessors (Burrows and Harvey, 1992). It has been argued that perceptions of quality affect approaches been applied to assure quality, and also different stakeholders think about quality in different ways (Elassy, 2015; Udam and Heidmets, 2013). This has led to conflicts among stakeholders (Pham and Starkey, 2016). Razavi et al. (2012) posit that customer or stakeholder satisfaction is the ultimate goal to achieve quality higher education. Hence, stakeholder needs and expectations must be met to achieve quality higher education.

Higher education administrators (HEAs) confront an ever-declining student population and an oversupply of capable higher education service providers, including growth of the distance education market via the internet (Emiliani et al. 2005). Most of the degree programs are quickly imitated by competitors, leaving administrators to compete on the basis of price. Thus, HEAs must focus on increase in enrollments and global ranking among others for success (Sunder, 2016). Notwithstanding, increasing enrollment could translate into several low-quality students who might not be able to cope with their studies. A US National Governors Association (1986) study, suggests that international competition and the increasing number of students entering higher education with lower levels of academic preparation heightened worries about the quality of higher education. HEAs by increasing enrollment, may translate into a larger class size which may be in conflict with the teacher's or student's definition of quality. HE teachers may prefer a smaller student per teacher ratio in terms of quality.

Marginson and Van der Wende (2007) had criticized HEAs for focusing on global ranking to achieve quality. They had argued that global rankings by Shanghai Jiao Tong University and the 
Times Higher Education (2015) neither provide guidance on the quality of teaching and had recommended a "clean" ranking, transparent, free of self-interest, and methodologically coherent, to improve the quality of higher education (Marginson and Van der Wende, 2007).

HEAs have also been criticized for developing good specialist professionals, and unable to produce well-rounded graduates and, in particular, those who understand business process orientation and cross-functional integration (Kavanagh and Drennan, 2008). HE teachers are promoted based on their research, teaching and service to the community. Employers end up retraining these not 'well rounded and trained graduates' at a higher cost to suit their needs (Green, 1994). The nature of HE teaching will need to become not only more varied and versatile, but will also have to be of a very high quality to exceed stakeholder expectations.

Research suggests that despite the calls for accountability and reform in higher education, there is insufficient stakeholder dialogue and consensus (Bogue and Hall, 2012; Morse, 2014; Zemsky, 2009). Although stakeholders agree that higher education is in need of reform, there is insufficient knowledge about the extent to which major stakeholders align or differ on various characteristics of accountability (Bogue and Hall, 2012). From these perspectives, the needs and expectations of the major stakeholders (HE governing council, HE administrators, students, and teachers) should create the needed environment for institutional change and improvement (Hess and Benjamin, 2015).

Brint and Clofter, (2016) had suggested that most studies are principally interested how HEIs work and what forces in their environments lead them to change. However, most policymakers do not want simply to understand HEI systems, but rather to know how to make them work better than they currently do to achieve quality higher education. HE institutions must focus on the needs or expectations of its stakeholders to achieve quality higher education. Consequently, the goals, objectives, and focus of some of the major stakeholders in HEIs that are conflicting must be resolved. The aim of this study is to identify a tool to resolve some of these conflicts within stakeholder expectations. To achieve this aim, we investigate the question to what extent do HEAs meet the major stakeholders' expectations?

\section{Tools Available for Managing Stakeholder Conflicts and Challenges in Implementation}

In this competitive HE environment, the survival of the institution depends on the ability to meet and exceed stakeholder expectations. Hence, the HEA must identify new tools, technologies and systems to improve the quality of higher education by translating the voice of the customer (stakeholder expectation) into critical to quality (CTQs) characteristics.

Studies have found that that HE stakeholders hold diverse perspectives on quality and are reluctant to use the results of accreditation evaluation reports because of conflicts of interest (Fenwick, 2016; Pham and Starkey, 2016; Miller, 2016). Challenges in implementing the quality initiatives to resolve some of these conflicts include: resistance to change by administrators, teachers and staff members; lack of time; short-term thinking; stuck on tradition; "what is in it for me" mentality and lack of support from team members (Akao, 1990; Aly and Akpovi, 2001). According to Vazzana et al. (1997), quality initiatives are widely practiced in HEIs, for example, there is some criteria for HEIs to fulfil in the Malcolm Baldridge National Quality Award. Though, Karapetrovic et al. (1999) indicated that without methodical approach to improving quality, the initiatives to 
improve higher education may be doomed for failure. Venkatraman (2007) posits that in HEIs, service quality deals with the students, the time of delivery of programs, the intangibility (for example, the learning process being subtle to be measured) and the difficulty in measuring successful output and productivity in quality. However, Hwarng and Teo (2001) writes that a critical step in implementing quality in HE is to identify the current and potential stakeholders. Thus, stakeholders' focus must provide direction for higher education quality improvement initiatives.

Other studies by measuring the quality of higher education have used the SERVQUAL (Parasuraman et al. 1985; Tuan, 2012), and the HEdPERF (Abdullah, 2006) and HiEdQual (Annamdevula and Bellamkonda, 2012) models. Notwithstanding, a long-term Harvard study found that, institutions that blindly fulfil stakeholder's expectations, did less well than institutions that balanced the interests of all their stakeholders (Caulkin and Black, 1994; Kotter and Heskett, 1992). Nonetheless, Abidin (2015) had argued that the differences in SERVQUAL, HEdPERF and HiEdQual models show that service quality varies, depending on the research objective and the stakeholder group, and therefore, unsuitable for our purpose in this study. Hence, the tool must help the HEA improve the existing processes by balancing the interests of all their stakeholders, that will ensure the maximum results in quality higher education.

The Quality Function Deployment (QFD) (Akao, 1997) and the Kano et al. (1984) model are tools that have been used extensively to identify and translate the voice of customer (critical to quality - CTQ) or stakeholder expectations to improve quality (Al-Bashir, 2016; Tetteh, 2015). Previous research acknowledges the risk of the HEA solely relying on his/her expectations to achieve quality higher education (Keller et al. 2014). Although QFD (Yeh, 2010) and SERVQUAL (Sulisworo and Maniquiz, 2012) methodologies has been used to improve quality, the Kano et al. (1984) model has been shown to be more beneficial (Paraschivescu and Cotirlet, 2012; Sulisworo and Maniquiz, 2012). Also, Lo et al. (2016) write, that it is a challenge for traditional QFD to accurately recognize customer expectations. The Kano et al. (1984) model, and its related theory and methodology, is well established and has been applied extensively in the field of education (Tetteh, 2015; Witell et al. 2013). The Kano et al. (1984) model has stated that blindly fulfilling stakeholder expectations has risk associated with it if the product or service provider is not aware that there are different types of stakeholder requirements. Lately, research has been published on practical applications of the Kano et al. (1984) model in translating the voice of customer to improve quality ((Mitrabasu, 2013; Paraschivescu and Cotirlet, 2012; Sulisworo and Maniquiz, 2012). While a number of papers has been published on the applications of the Kano et al. (1984) model, scarcely have one used the model to resolve conflicts among major stakeholders in the HE system (see Chang and Chang, 2012; Gustavsson et al. 2016; Keller et al. 2014; Shahin et al. 2017). The Kano et al. (1984) model is useful for incorporating stakeholder expectations into the design of processes (Mikulic and Prebezac, 2011). As also concluded by Walden (1993), the Kano et al. (1984) model analysis has the potential to increase confidence in the analysis of stakeholder expectations. Thus, by choosing the Kano et al. (1984) model from the review, we will overcome the gap in terms of focusing on a sole stakeholder, and blindly fulfilling stakeholder expectations. 


\section{Method}

\section{Kano et al. (1984) Model}

The Kano et al. (1984) model is employed to identify the stakeholder expectations that are critical to quality (CTQs) and the functional requirements (FR) to help improve the quality of higher education. To that end, Sunder (2016), proposed stakeholder expectations (CTQ) that are used to generate what the stakeholder needs or expects in this study. The traditional Kano et al. (1984) model is an approximate estimate of the stakeholder 's expectation which only allows attributes of qualitative assessment of the expectations (Wassenaar et al. 2005). We employed some quantitative measures to assign some scales in terms of the levels of stakeholder satisfaction or dissatisfaction (Berger et al. 1993; Matzler and Hinterhuber, 1998).

Based on the Kano et al. (1984) model, the FR of each variable were initially classified (using the functional and dysfunctional form of Kano et al. (1984) questions) as Exciter or Attractive (A), Must-be (M), One-dimensional (O), and Indifferent (I) as depicted in Table 1.

Table 1. Kano evaluation table

Source: (Kano et al. 1984).

\begin{tabular}{|c|c|c|c|c|c|c|}
\hline & \multicolumn{5}{|c|}{ Dysfunctional Questions } \\
\hline & & $\begin{array}{l}\text { Like } \\
\text { it } \\
\text { that } \\
\text { way }\end{array}$ & $\begin{array}{l}\text { Must be } \\
\text { that way }\end{array}$ & $\begin{array}{l}\text { I am } \\
\text { neutral }\end{array}$ & $\begin{array}{l}\text { Can live } \\
\text { with it } \\
\text { that way }\end{array}$ & $\begin{array}{l}\text { Dislike it } \\
\text { that way }\end{array}$ \\
\hline \multirow{5}{*}{ 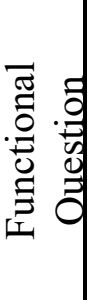 } & Like it that way & $\mathrm{Q}$ & $\mathrm{E}$ & $\mathrm{E}$ & $\mathrm{E}$ & $\mathrm{O}$ \\
\hline & Must be that way & $\mathrm{R}$ & I & I & I & M \\
\hline & I am neutral & $\mathrm{R}$ & $\mathrm{I}$ & $\mathrm{I}$ & I & M \\
\hline & Can live with it that & $\mathrm{R}$ & $\mathrm{I}$ & $\mathrm{I}$ & I & M \\
\hline & Dislike it that way & $\mathrm{R}$ & $\mathrm{R}$ & $\mathrm{R}$ & $\mathrm{R}$ & Q \\
\hline
\end{tabular}

E: Exciter or Attractive, O: One-dimensional, M: Must be, I: Indifferent, R: Reverse, Q: Questionable.

For each variable, a contingency output was generated (between functional and dysfunctional questions) and the frequencies of respondents summed according to the classification structure (where the letters represent the Kano et al. (1984) stakeholder groups). A functional question captures the stakeholders' response if an expectation has a certain attribute, and a dysfunctional form question if an expectation does not have that attribute. A Questionable (Q) category will not be included in the averages, and a Reverse (R) category can be transformed out of the category by reversing the sense of functional and dysfunctional of questions (Berger et al. 1993). To fully exploit these insights, all the needs and the expectations of the major stakeholders must be analyzed and ranked to: Dissatisfier - Must be; Satisfier - More is better; and Exciter - Latent Need by using the Kano et al. (1984) model (Tetteh, 2015).

Following $\mathrm{Xu}$ et. al. (2009), this study adopts a scoring scheme that defines stakeholder's satisfaction (using functional questions) and dissatisfaction (using dysfunctional questions) as depicted in Table 2 below. The scale is designed to be asymmetric because positive answers are considered to be stronger responses than negative ones (Tetteh, 2015; Xu et al. 2009). 
Table 2. Scores for functional/dysfunctional features

Source: (Xu et al. 2009).

\begin{tabular}{|l|c|c|}
\hline & Functional Form questions & Dysfunctional Form questions \\
\hline Like it that way & 1 & -0.5 \\
\hline Must be that way & 0.5 & -0.25 \\
\hline I am neutral & 0 & 0 \\
\hline Can live with it that way & -0.25 & 0.5 \\
\hline Dislike it that way & -0.5 & 1 \\
\hline
\end{tabular}

\section{Participants}

This study settled on a cross-sectional survey design to examine the expectations of the major stakeholders (academic leaders, administrators, teachers and students) to achieve quality higher education leading to the formation of the four groups (Creswell, 2012). This categorization was done through a brainstorming session with the academic leaders and administrators, as in Emery and Tian (2002) study. To reduce coverage and sampling error, a list of the target population (sometimes called the sampling frame), was obtained from five higher education institutions (public and private) in Accra, Ghana and they were randomly selected to become participants (Salant and Dillman, 1994). HEAs participated in this study, as their positions placed them in a position likely to provide rich sources of information on how quality of higher education was perceived. This aimed at ensuring "the maximum variation sampling" (Patton, 2002; Pham and Starkey, 2016). Two hundred (200) participants were randomly selected after a passive consent procedure was employed. None of the participants were pressured to participate, and all were assured that it was a voluntary activity. The major stakeholders were represented by $20(10 \%)$ academic leaders, $38(19 \%)$ administrators, $37(19 \%)$ teachers and $105(53 \%)$ students. Out of the 200 participants, $106(53 \%)$ were males and 94 (47\%) were females.

The author acted as an action researcher, conducting research within the Ghanaian higher education institutions (Coghlan and Brannick, 2008). Two sources were used for data collection, first, an email of which 113 responses were used. Second, face to face interviews which lasted about 45 minutes were recorded and transcribed. The use of multiple data sources could be considered triangulation, which serves to strengthen the findings (Bryman and Bell, 2007). A reflective dialogue between the researcher and the stakeholders was used to sort out the expectations, which increased the understanding, credibility, and internal validity of stakeholder expectations. (Eisenhardt, 1989).

The data for this research were collected through participative observations and interviews with the major stakeholders. An overlap between data collection and data analysis allowed the researchers to iteratively collect and analyze data (Coghlan and Brannick, 2008; Meredith, 1998). A qualitative content analysis (Flick, 2014) was carried out focusing on practical implications of the Kano et al. (1984) model and the relation to different stakeholder expectations to improve the quality of higher education. Thus, the data were related to the theoretical framework through a second-order analysis of the empirical material (Gustavsson et al. 2016; Reason and Bradbury, 2009; Tetteh, 2015).

\section{Instrument}

The Sunder (2016) and Kano et al. (1984) questionnaire were slightly modified to fit the present study and measure the major stakeholder expectations as depicted in Table 3 in the Appendix. 
For each question, respondents could then answer in five different ways following a 5-point Likert scale (Likert 1932): (1) I like it that way, (2) It must be that way, (3) I am neutral, (4) I can live with it that way, and (5) I dislike it that way. The categorization was done through a brainstorming session with the academic leaders and administrators, as in Emery and Tian (2002) study. The attributes were then placed in the Kano et al. (1984) model based on their influence on stakeholder satisfaction.

\section{Study Design Relevance - Reliability and Validity of Outcome Measures}

The reliability of a scale indicates how the design is free from random error. The aspect of reliability assesses the internal consistency of the major stakeholder expectations. A total of 88 items were selected for identifying the major stakeholder expectations. In determining the reliability of the instrument, a general rule is that the indicator should have a Cronbach's alpha of 0.60 or more (Nunnally, 1978). The Cronbach's alpha for the 88 items were 0.891 as depicted in Table 4 in the Appendix, indicating that the instrument was reliable and suitable for analysis.

Table 4. Reliability Statistics

\section{Reliability Statistics}

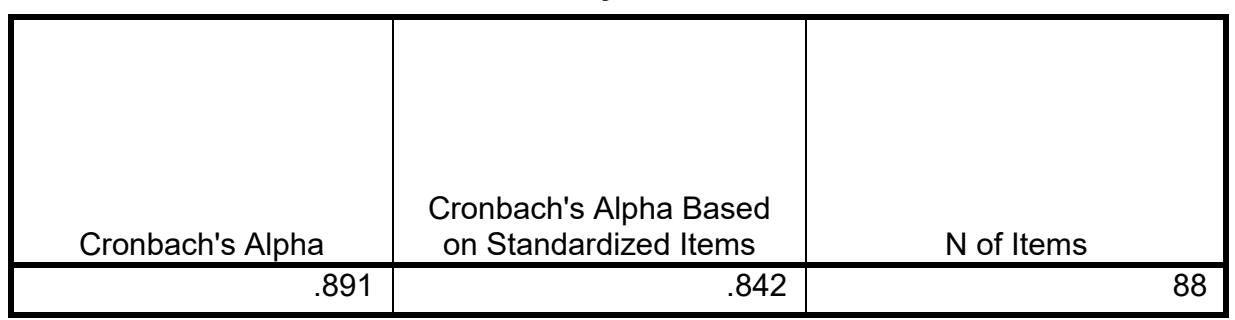

Summary Item Statistics

\begin{tabular}{|l|r|r|r|r|r|r|r|}
\hline & Mean & Minimum & Maximum & Range & \multicolumn{1}{c|}{ Maximum / } & Variance & N of Items \\
& & 4.693 & 1.855 & 7.510 & 5.655 & 4.049 & 3.669 \\
Item Means & 1.935 & .462 & 4.635 & 4.173 & 10.040 & 1.783 & 88 \\
Item Variances & .002 & -.763 & .814 & 1.577 & -1.067 & .306 & 88 \\
Inter-Item Correlations & & & & & \\
\hline
\end{tabular}

\section{ANOVA}

\begin{tabular}{|ll|r|r|r|r|r|}
\hline & & Sum of Squares & df & Mean Square & F & Sig \\
\hline \multirow{2}{*}{ Between People } & & 1304.591 & 199 & 6.556 & & \\
& Between Items & 63836.979 & 87 & 733.758 & 389.981 & .000 \\
Within People & Residual & 32574.839 & 17313 & 1.882 & & \\
& Total & 96411.818 & 17400 & 5.541 & & \\
Total & & 97716.409 & 17599 & 5.552 & & \\
\hline
\end{tabular}

Grand Mean $=4.69$ 
Hotelling's T-Squared Test

\begin{tabular}{|c|c|c|c|c|}
\hline $\begin{array}{c}\text { Hotelling's T- } \\
\text { Squared }\end{array}$ & F & df1 & \multicolumn{1}{c|}{ df2 } & \multicolumn{1}{c|}{ Sig } \\
\hline 93985.893 & 613.435 & 87 & 113 & .000 \\
\hline
\end{tabular}

Based on the findings of Tetteh (2015), the level of importance of the functional requirements (FR) were determined by the application of factor analysis (principal component technique). The use of factor analysis method demands the existence of correlation among the variables of interest and also the adequacy of the sample in order for the factors formed to account for higher variation in the variables. To achieve construct validity, the data were examined using principal component analysis as the extraction technique and the varimax as the method of rotation. With a cutoff loading of 0.50 and an Eigen value greater than 1.0, none of the items were dropped. Our assumption of using the factor analysis method conformed to McNaught et al. (2007) testing the validity of the Recovery Assessment Scale (RAS).

The high statistics of Bartlett's Test of Sphericity (18679.340) with the corresponding small significant value (0.0005) confirmed the existence of strong correlation among the responses and the Kaiser-Meyer-Olkin (KMO) statistics of 0.967 which is greater than 0.500 indicated a strong sampling adequacy and hence reliability of the data (sample) for the factor analysis technique as depicted in Table 5 below.

Table 5. KMO and Bartlett's Test

KMO and Bartlett's Test

\begin{tabular}{|c|c|c|}
\hline \multicolumn{2}{|c|}{ Kaiser-Meyer-Olkin Measure of Sampling Adequacy. } & .967 \\
\hline Bartlett's Test of Sphericity & Approx. Chi-Square & 18679.340 \\
\hline & df & 4095 \\
\hline & Sig. & 0.000 \\
\hline
\end{tabular}

\section{Results}

The focus of this paper was to resolve the conflicts with the expectations of the major stakeholders in the higher education institutions using the Kano et al. (1984) model. The Kano indices were computed to obtain the configuration index for each of the major stakeholder expectations as Exciter or Attractive, Must-be, One-dimensional, or Indifferent based on a model proposed by Berger et al., (1993) as depicted in Figure 1. Our results indicated: Exciter or Attractive - 18. Student's absenteeism; Must-be: - 3. Turnaround time for admission process, 7. Number of students placed at corporate jobs, 8. Salary range of passed alumni from the university, 13. Increase in research papers published per department; One-dimensional- 11. Increase in students' enrollment, 14. Quality of research, 15. University maintenance culture, 16. Food wastage in university cafeteria, 17. Standard of teaching, 20. Paper consumption in the university, 21. Accreditation Process, 22. Accreditation would ensure quality; and Indifferent-1. Pass percentage of students in a class, 2. Turnaround time for issuing books in the library, 4. Overall student satisfaction score, 5. Computer laboratory equipment availability, 6. Computer systems downtime at the university,9. Residential facilities at hostel rooms, 10. Facilities for gymnasium and sports center, 12. University ranking, 19. Accuracy of medical prescriptions at university's clinic. 
Figure 1. Stakeholder Expectations with Kano et al. 1984 Indices

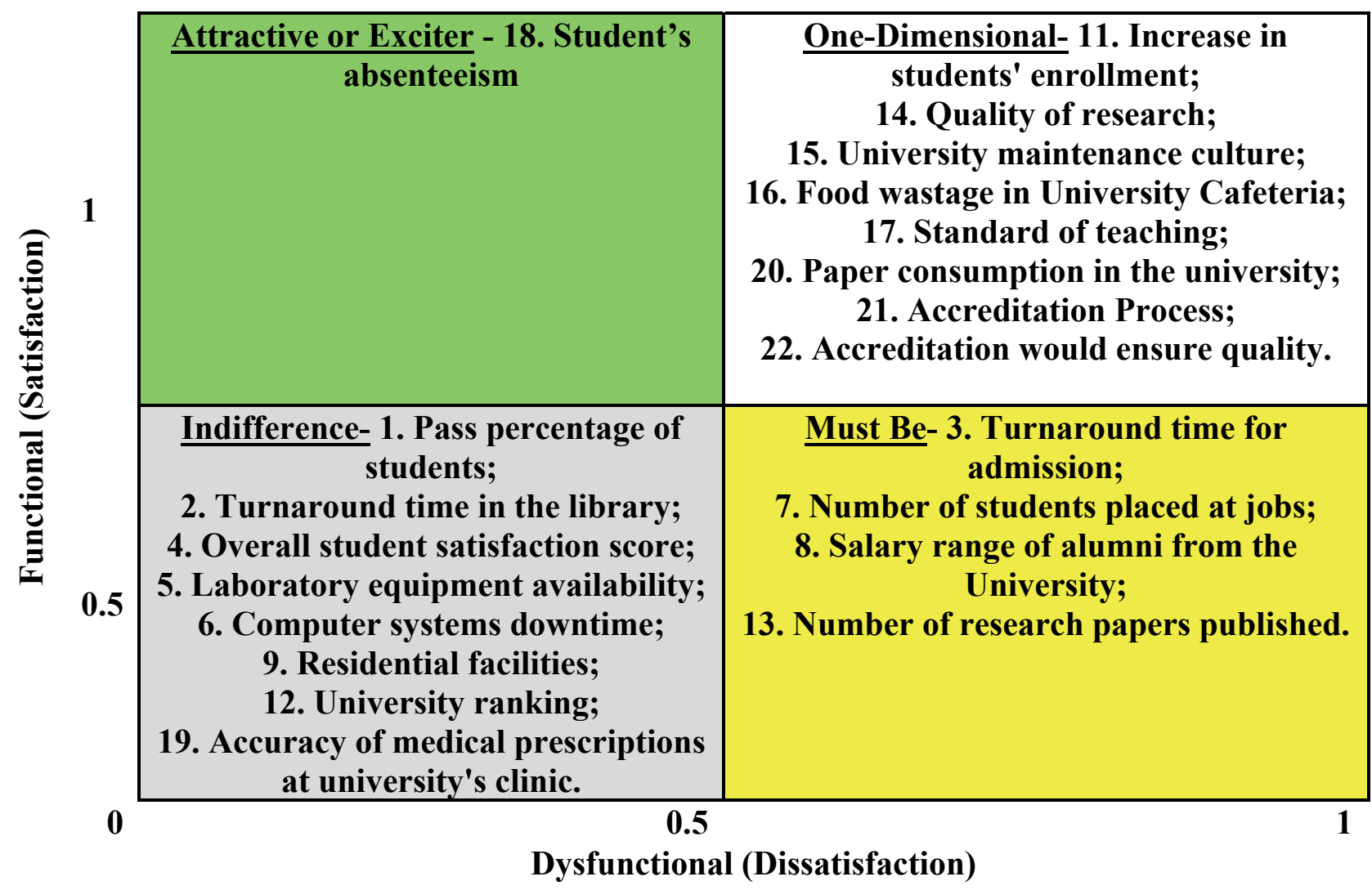

By comparing the prioritized stakeholders' expectations into Exciter or Attractive, Must-be, Onedimensional, or Indifferent using the Kano et al. (1984) model, the HEA could intuitively take a decision as shown in Figure 1 (Jeon et al. 2012). The results indicate that strategies to minimize student absenteeism would excite students, while these must-be qualities must be taken into consideration to avoid dissatisfaction of the students.

\section{Discussion}

The uniqueness of our study lies in the application of the Kano et al. (1984) to resolve conflicts by incorporating a perspective of understanding the criticality of needs or expectations from the major stakeholders such as academic leaders, administrators, teachers and students (Bate and Robert, 2007; Jeon et al. 2012; Lengnick-Hall, 1995). The various roles of a student, for example, treated as a customer (Gruber et al., 2010) in the higher education process, would ensure quality of higher education and improve institutions.

Our study supports what is argued by Sulisworo and Maniquiz (2012), that the Kano et al. (1984) model is a practical tool for the quality of higher education to classify different stakeholder expectations, monitor their expectations and prioritize the various action plans required to improve the system. As an example, in the Kano et al. (1984) model, both the 'spoken' (one-dimensional) and 'unspoken' (attractive and must-be) expectations of the stakeholders are visualized. However, the same methods cannot be used to collect data on spoken and unspoken expectations. Direct methods like interviews can aid in identifying spoken expectations, whereas indirect methods like 
observations are necessary to identify unspoken expectations. Earlier studies (Keller et al. 2014; Paraschivescu and Cotirlet, 2012), had indicated a challenge in using only stakeholder input from surveys or interviews when collecting expectations, as the unspoken expectations will be missing.

This study confirms this challenge, but also points to a way of overcoming it. That is, the challenge can be overcome by not only collecting stakeholder input through methods such as surveys, but also allowing HE internal and external stakeholders to provide input (Gustavsson et al. 2016; Lengnick-Hall, 1995). Hence, it is not only critical to use a variety of methods to collect stakeholder's expectations, but it is also critical to involve a variety of respondent groups providing an input on expectations related to the various stakeholder roles.

\section{Theoretical and Practical Implications}

This study suggests that HEAs must concentrate on strategies that reduce or minimize student absenteeism as an exciter or attractive quality, rather than global ranking which is an indifferent quality (Balfanz and Byrnes, 2013). Attractive quality is an attribute that provides satisfaction when achieved fully, but do not cause dissatisfaction when not fulfilled. On the other hand, indifferent attribute refers to aspects that are neither good nor bad, and they do not result in either customer satisfaction or customer dissatisfaction.

This study confirms Kano et al. (1984) conclusion that blindly fulfilling stakeholder/customer expectations had risks such as providing superfluous quality. That is wowing the stakeholder/customer in one area, and driving them to competitors in another; and focusing only on what stakeholder/customer say, and not what they think (Kano et al. 1984; Woodham et al. 2017).

\section{Conclusions}

The results of this study found student absenteeism as an attractive quality. Indeed, out of 15 different types of reasons for student absenteeism from an earlier study, factors relating to courses and teachers were found to be the least significant (Longhurst, 1999). Consequently, students just go through the motions because of the dearth of reasonably attractive jobs available to them, and parental and peer group pressure (UN Sustainable Development Goals, 2016).

The main contribution of this study is to resolve the major stakeholder's conflicts in the HEIs using the Kano et al. (1984) model. Looking at the various roles is a way to realize the necessity of capturing input from various stakeholders (such as academic leaders, administrators, teachers and students). Further, it is important to apply various methods in collecting data when assessing stakeholder expectations, as some of the expectations are explicit (expressed or spoken) and implicit (implied or unspoken). This study contributes to knowledge on how to combine the stakeholder expectations to resolve conflicts using the Kano et al. (1984) model.

\section{Limitations and Directions for Further Research}

There are a number of limitations to our study. This study has drawn conclusion based on responses from stakeholders in private and public higher institutions in Accra, Ghana; hence, the outcome cannot be generalized. Notwithstanding, the findings could provide valuable insights to HEAs in HEIs. 
Further studies, could address how to initially capture stakeholder expectation as an input before becoming a stakeholder. In order to capture these types of expectations, data collection from other respondent groups, such as external stakeholder (national university commission (NUC), nongovernmental organizations, community based organizations, parents, employers of labor, trade unions, alumni association, industries/firms, might be a way forward in future research.

\section{References}

Abdullah, F. (2006), "The development of HEdPERF: a new measuring instrument of service quality for the higher education sector." International Journal of Consumer Studies, Vol. 30 No.6, pp. 569-581. http://dx.doi.org/10.1111/j.1470-6431.2005.00480.x. [Accessed 27 July 2016].

Abidin, M. (2015), "Higher Education Quality: Perception Differences among Internal and External Stakeholders," International Education Studies; Vol. 8, No. 12, pp. 185-191 http://dx.doi.org/10.5539/ies.v8n12p185.

Akao, Y. (1990), (Ed.), Quality Function Deployment, Integrating Customer Requirements into Product Design, Productivity Press, Cambridge, MA.

Akao, Y. (1997), QFD: Past, present, and future. In International Symposium on QFD '97. Linköping, Sweden. Available at http://www.cadlab.tuc.gr/webmaster/06_QFD_PpF .pdf. [Accessed 27 July 2016].

Al-Bashir, B. (2016), "Applying Total Quality Management Tools Using QFD at Higher Education Institutions in Gulf Area (Case Study: ALHOSN University)", International Journal of Production Management and Engineering, pp. 87-98. doi:10.4995/ijpme.2016.4599.

Aly, N. and Akpovi, J. (2001),"Total quality management in California public higher education", Quality Assurance in Education, Vol. 9 Iss. 3 pp. 127 - 131.

Annamdevula, S., and Bellamkonda, R. S. (2012), "Development of HiEdQUAL for Measuring Service Quality in Indian Higher Education Sector", International Journal of Innovation, Management and Technology, Vol. 3 No.4, http://dx.doi.org/10.7763/IJIMT.2012.V3.265. [Accessed 27 July 2016].

Asiyai, R. I. (2015), "Improving Quality Higher Education in Nigeria: The Roles of Stakeholders," International Journal of Higher Education, Vol. 4, No.1, pp.61-70.

Balfanz, R. and Byrnes, V. (2013), Meeting the challenge of combating chronic absenteeism: Impact of the NYC Mayor's Interagency Task Force on chronic absenteeism and school attendance and its implications for other cities. Everyone Graduates Center, Johns Hopkins University School of Education. Available at: https://static1.squarespace.com/static/56bb3ecb27d4bd8dbfa37853/t/56ff0b124d088e778 1 fa9622/1459555093032/NYC-Chronic-Absenteeism-Impact-Report-Nov-2013.pdf [Accessed 27 July 2016].

Bate, P. and Robert, G. (2007), "Toward more user-centric OD: lessons from the field of experience-based design and a case study", The Journal of Applied Behavioral Science, Vol. 43 No. 1, pp. 41-66.

Berger, C., Blauth, R., Boger, D., Bolster, C., Burchill, G., DuMouchel, W., Pouliot, F., Richter, R., Rubinoff, A., Shen, D., Timko, M. and Walden, D. (1993), "Kano's method for understanding customer-defined quality", Center for Quality of Management Journal Vol. 2 No. 4, pp. 3-35. 
Bogue, G. and Hall, K. (2012), "Corporate, Academic, and Political Perspectives on Higher Education Accountability Policy," College \& University Journal, Vol. 87 No.3, pp. 14-23.

Brint, S. and Clotfelter, C.T. (2016), "U.S. Higher Education Effectiveness," The Russell Sage Foundation Journal of the Social Sciences, Vol. 2 No.1, pp. 2-37.

Bryman, A. and Bell, E. (2007), Business Research Methods, 2nd ed., Oxford University Press, New York, NY.

Burrows, A. and Harvey, L. (1992), "Defining quality in higher education: the stakeholder approach", paper presented at the AETT Conference on Quality in Education, University of York.

Caulkin, S., and Black, M. (1994), "The new corporate crusade: A wider social and economic role is now expected of the corporate sector." Management Today, October, pp. 56-60.

Chang, W.-J. and Chang, Y.-H. (2012), "Patient satisfaction analysis: identifying key drivers and enhancing service quality of dental care”, Journal of Dental Sciences, Vol. 8 No. 3, pp. 239-247.

Chong, S. (2014), “Academic quality management in teacher education: a Singapore perspective”, Quality Assurance in Education, Vol. 22 No. 1, pp. 53-64.

Coghlan, D. and Brannick, T. (2008), Doing Action Research in Your Own Organization, Sage Publications Ltd, London.

Cole, J. R. (2009), The Great American University: Its Rise to Preeminence, Its Indispensable National Role, Why It Must be Protected. New York: Perseus Books.

Creswell, J.H. (2012), Educational Research-Planning, Conducting, and Evaluating Quantitative and Qualitative Research (4 ${ }^{\text {th }}$ Edition). Upper Saddle River, NJ: Pearson Prentice Hall.

Eisenhardt, K.M. (1989), "Building theories from case study research", Academy of Management Review, Vol. 14 No. 4, pp. 532-550.

Elassy, N. (2015), "The concepts of quality, quality assurance and quality enhancement", Quality Assurance in Education, Vol. 23 No. 3, pp. 250-261.

Emery, C.R. and Tian, R.G. (2002), "Schoolwork as products, professors as customers: a practical teaching approach in business education." Journal of Education for Business, Vol. 78 No.2, pp.97-102.

Emiliani, B., Kensington, C. and Most, U.S. (2005), "Lean in international higher education." Center for Lean Business Management. Available at http://www.superfactory. com/articles/lean_higher_ed.aspx. [Accessed 11 December 2016].

Fenwick, T., (2016) "Social media, professionalism and higher education: a sociomaterial consideration" Studies in Higher Education, Vol 41, No. 4) pp.664-677.

Finch, J. (1994), "Quality and its Measurement: A Business Perspective" in Green, D. (ed.) What is quality in international higher education? Taylor \& Francis, Bristol, p.63 Open University Press. Available at: http://repositorio.ub.edu.ar:8080/xmlui/bitstream/handle/123456789/2124/6.pdf?sequene $=1$ [Accessed 11 December 2016].

Flick, U. (2014), An Introduction to Qualitative Research. Sage, London.

Freeman, R.E. (1984), Strategic Management: A Stakeholder Approach, Pitman, Toronto, ON. Friedman, A.L. and Miles, S. (2006), Stakeholders: Theory and practice. Oxford University Press. Ganguli, S. and Roy, S.K. (2011), "Generic technology-based service quality dimensions in banking: impact on customer satisfaction and loyalty", International Journal of Bank Marketing, Vol. 29 No. 2, pp. 168-189. 
Goldin, C. and Katz, L.F. (2008), The Race Between Education and Technology. Cambridge, Mass.: The Belknap Press of Harvard University Press.

Green, D. (1994), What is quality in international higher education? In Green, D. (ed.) Society for Research into International higher education, Open University Press. Available at: http://repositorio.ub.edu.ar:8080/xmlui/bitstream/handle/123456789/2124/6.pdf?sequene $=1$ [Accessed 11 December 2016].

Gruber, T., Reppel, A. and Voss, R. (2010), "Understanding the characteristics of effective professors: the student's perspective", Journal of Marketing for International higher education Vol. 20 No. 2, pp. 175-190.

Gustavsson, S., Gremyr, I. and Sarenmalm,E.K. (2016),"Using an adapted approach to the Kano model to identify patient needs from various patient roles ", The TQM Journal, Vol. 28 Iss 1 pp. $151-162$.

Hatami, H., Rangraz, E. and Jahromi, M. (2016), "Survey the relationship between inter personal conflict and organizational communications in personnel of physical education offices of Alborz province." International Journal of Humanities and Cultural Studies (IJHCS)ISSN 2356-5926, pp.

2208-2215.

Availableat:http://www.ijhcs.com/index.php/ijhcs/article/view/2370/2185. [Accessed 10 October 2016].

Hess, J.D, and Benjamin, B.A. (2015),"Applying Lean Six Sigma within the international higher education: opportunities for process improvement and cultural change", International Journal of Lean Six Sigma, Vol. 6 Iss. 3 pp. 249 - 262.

Hwarng, H.B., and Teo, C. (2001),"Translating customers' voices into operations requirements A QFD application in higher education", International Journal of Quality \& Reliability Management, Vol. 18 Iss 2 pp. 195 - 226.

Jeon, C.K., Kim, N.H., Lee, D.H., Lee, T. and In, H.P. (2012), "Stakeholder Conflict Resolution Model (S-CRM) Based on Supervised Learning." KSII Transactions on Internet \& Information Systems, Vol. 6 No.11, pp. 2813-2826. Available at: http://dblp.unitrier.de/db/journals/itiis/itiis6 (accessed 12 March 2017).

Kanji, G.K., Malek, A. and Tambi, B.A. (1999), "Total quality management in UK higher education institutions", Total Quality Management, Vol. 10 No. 1, pp. 129-153.

Kano, N., Seraku, N., Takahashi, F. and Tsuji, S. (1984), “Attractive quality and must-be quality”, The Journal of the Japanese Society for Quality Control, Vol. 14 No. 2, pp. 39-48.

Karapetrovic, S., Rajamani, D. and Willborn, W. (1999), "University, Inc.", Quality Progress, Vol. 32 No. 5, pp. 87-95.

Kavanagh, M. and Drennan, L. (2008), "What skills and attributes does an accounting graduate need? Evidence from student perceptions and employer expectations", Accounting and Finance, Vol. 48, pp. 279-300.

Keller, A.C. , Bergman, M.M. , Heinzmann, C. , Todorov, A. , Weber, H. and Heberer, M. (2014), "The relationship between hospital patients' ratings of quality of care and communication", International Journal for Quality in Health Care, Vol. 26 No. 1, pp. 26-33, available at: http://intqhc.oxfordjournals.org/content/early/2013/11/19/intqhc.mzt083.short[Accessed 27 July 2016].

Kotler, P. (2012), Kotler On Marketing, Simon and Schuster Publications, New York, NY.

Kotter, J. P., and J. L. Heskett (1992), Corporate Culture and Performance. New York: The Free Press. 
Kreps, G.L (1990), Organizational communication: Theory and practice. (2 ${ }^{\text {nd }}$ Edition) New York, NY: Pearson.

Kumar, V., Rahman, Z. and Kazmi, A.A. (2016),"Stakeholder identification and classification: a sustainability marketing perspective ", Management Research Review, Vol. 39 Iss 1 pp. 35 -61 .

Lengnick-Hall, C. (1995), "The patient as the pivot point for quality in health care delivery", Hospital \& Health Services Administration Special CQI Issue, Vol. 40 No. 1, pp. 25-39.

Likert, R. (1932), "A Technique for the Measurement of Attitudes", Archives of Psychology Vol. 2 No. 140, pp. 1-55.

Lo, S. M., Shen, H and Chen, J.C. (2016), "An integrated approach to project management using the Kano model and QFD: an empirical case study," Total Quality Management \& Business Excellence, pp. 1-26. DOI: 10.1080/14783363.2016.1151780.

Longhurst, R.J. (1999), "Why aren't they here? Student absenteeism in a further education college." Journal of Further and Higher Education, Vol. 23 No.1, pp.61-80.

Luxford, K., Safran, D.G. and Delbanco, T. (2011), "Promoting patient-centered care: a qualitative study of facilitators and barriers in healthcare organizations with a reputation for improving the patient experience", International Journal of Quality in Health Care, Vol. 23 No. 5, pp. 510-515.

Mabokela, R.O. (2002), Voices of conflict: desegregating South African universities. Routledge New York and London. Available at: https://books.google.com.gh/books?id=6fuOAgAAQBAJ\&printsec=frontcover\&dq=isbn: $1135578990 \& h l=e n \& s a=X \& v e d=0 a h U K E w i t w K b h 0$ svRAhVEBBoKHaGbC4EQ6AEIG

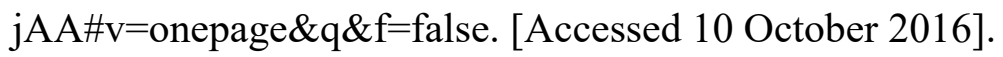

Marginson, S. and Van der Wende, M. (2007), "To rank or to be ranked: The impact of global rankings in higher education." Journal of Studies in International Education, Vol. 11 Is.34, pp.306-329.

Matzler, K. and Hinterhuber, H. H., (1998), "How to make product development projects more successful by integrating Kano's model of customer satisfaction into quality function deployment", Technovation Vol. 8 No.1, pp. 25-38.

Mazur, G. (2003), "Voice of the customer (define): QFD to define value", ASQs Annual Quality Congress Proceedings, Kansas City, MI, 19-21 May, pp. 57.

McNaught, M., Caputi, P., Oades, L.G. and Deane, F.P. (2007), "Testing the validity of the Recovery Assessment Scale using an Australian sample." Australian and New Zealand Journal of Psychiatry, Vol. 41 No.5, pp.450-457.

Meredith, J. (1998), "Building operations management theory through case and field research", Journal of Operations Management, Vol. 16 No. 4, pp. 439-452.

Mergen, E., Grant, D. and Widrick, S.M. (2000), "Quality management applied to higher education", Total Quality Management, Vol. 11 No. 3, pp. 345-352.

Mikulic, J. and Prebezac, D. (2011), "A critical review of techniques for classifying quality attributes in the Kano model", Managing Service Quality, Vol. 21 No. 1, pp. 46-66.

Miller, B.A., 2016. Assessing organizational performance in higher education. John Wiley \& Sons.

Mitrabasu, N.C. (2013), "Integrating Kano model and Herzberg two factor theory to unveil the third quality factor of patient satisfaction in a multispecialty outdoor medical center", International Journal of Emerging Science and Engineering, Vol. 1 No. 7, pp. 1-5. 
Morse, A.Q. (2014), "Partisan Differences on Higher Education Accountability Policy: A MultiState Study of Elected State Legislators," Journal of Research in Education Volume 24, No. 2, pp. 173-192.

National Governors Association (1986), A Time for Results: The Governors' Report on Education. Washington, D.C.: National Governors Association.

Nunnally, J. C. (1978). Psychometric theory. New York, NY: McGraw-Hill.

Paraschivescu, A.O. and Cotirlet, A. (2012), "Kano model", Economy Transdisciplinary Cognition, Vol. 15 No. 2, pp. 116-124.

Parasuraman, A., Zeithaml, V. A., and Berry, L. L. (1985), “A conceptual model of service quality and its implications for future research", The Journal of Marketing, pp. 41-50. Retrieved from http://www.jstor.org/stable/1251430 [Accessed 27 July 2016]..

Patton, M.Q. (2002), Qualitative Research and Evaluation Methods, 3rd ed., Sage, London.

Pham, H.T. and Starkey, L., (2016) "Perceptions of higher education quality at three universities in Vietnam." Quality Assurance in Education, Vol. 24 No. 3, pp.363-369.

Pizam, A., Shapoval, V. and Ellis, T. (2016),"Customer satisfaction and its measurement in hospitality enterprises: a revisit and update", International Journal of Contemporary Hospitality Management, Vol. 28 Iss. 1 pp. 2 - 35.

Razavi, S. M., Safari, H., and Shafie, H. (2012), "Relationships among Service Quality, Customer Satisfaction and Customer Perceived Value: Evidence from Iran's Software Industry." Journal of Management and Strategy, Vol. 3 No.3, p. 28. http://dx.doi.org/10.5430/jms.v3n3p28 [Accessed 27 July 2016].

Reason, P. and Bradbury, H. (2009), The Sage Handbook of Action Research: Participative Inquiry and Practice, 2nd ed., Sage Publishing, Thousand Oaks, CA.

Salant, P. and Dillman, D.A. (1994), How to conduct your own survey. Wiley.

Shahin, A., Shahin, A., Mohammadi, S., Mohammadi, S., Harsij, H., Harsij, H., Rahbar Qazi, M.R. and Rahbar Qazi, M.R. (2017), "Revising satisfaction and dissatisfaction indexes of the Kano model by reclassifying indifference requirements: A case study of the presidential elections." The TQM Journal, Vol. 29 Iss. 1, pp.37-54.

Sharabi, M. (2013), "Managing and improving service quality in higher education", International Journal of Quality and Service Sciences, Vol. 5 No. 3, pp. 309-320.

Sulisworo, D. and Maniquiz, N.E.F. (2012), "Integrating Kano's model and SERVQUAL to improve healthcare service quality", International Conference on Green World in Business and Technology 2012, Yogyakarta, DIY, 23-24 March, pp. 130-144.

Sunder, M. V. (2016),"Lean Six Sigma in higher education institutions", International Journal of Quality and Service Sciences, Vol. 8 Iss 2 pp. 159 - 178.

Tetteh, G.A. (2015), "Improving learning outcome using Six Sigma methodology", Journal of International Education in Business, Vol 8 Iss. 1, pp.18-36.

Times Higher Education (2015), "World University Rankings 2014-15." https://www.timeshighereducation.com/world-university-rankings/2015/worldranking\#!/page/0/length/25[Accessed 27 July 2016].

Tuan, N. M. (2012), "Effects of service quality and price fairness on student satisfaction", International Journal of Business and Social Science, Vol. 3 No. 19, pp.132-150.

Udam, M. and Heidmets, M. (2013), "Conflicting views on quality: interpretations of 'a good university' by representatives of the state, the market and academia", Quality in Higher Education, Vol.19 No.2, pp. 210-224. 
UN Sustainable Development Goals (2016), Retrieved from http://www.un.org/sustainabledevelopment/education/. [Accessed 27 July 2016].

UNESCO (2014), EFA Global Monitoring Report 2013/4 - Teaching and Learning: Achieving Quality for All. Paris, UNESCO.

Usman, S. (2014), "Governance and higher education in Pakistan: what roles do boards of governors play in ensuring academic quality maintenance in public universities versus private universities in Pakistan." International Journal of Higher Education, Vol.3 No 2, pp. 38-51. http://dx.doi.org/10.5430/ijhe.v3n2p38 [Accessed 27 July 2016].

Vavra, T.G. (1997), Improving Your Measurement of Customer Satisfaction: A Guide to Creating, Conducting, Analyzing, and Reporting Customer Satisfaction Measurement Programs, ASQ Quality Press, Milwaukee, WI.

Vavra, T.G. (2002), Customer Satisfaction Measurement Simplified: A Step-By-Step Guide for ISO 9001: 2000 Certification, ASQ Quality Press, Milwaukee, WI.

Vazzana, G., Backmann, D. and Elfrink, J. (1997), "Does higher education practice what it teaches? ", Quality Progress, Vol. 30 No. 12, pp. 67-70.

Venkatraman, S. (2007), "A framework for implementing TQM in higher education programs. Quality Assurance in Education, Vol. 15 No.1, pp.92-112.

Walden, D. (1993), "Kano's methods for understanding customer-defined quality", Centre for Quality of Management Journal, Vol. 2 No. 4, pp. 2-36.

Wallace, J.B. (1999), “The case for student as customer”, Quality Progress, Vol. 32 No. 1, pp. 4751.

Wassenaar, H.J., Chen, W., Cheng, J. and Sudjianto, A. (2005), "Enhancing discrete choice demand modeling for decision-based design", ASME Journal of Mechanical Design Vol. 127, pp. 514-523.

Witell, L., Löfgren, M. and Dahlgaard, J.J. (2013), "Theory of attractive quality and the Kano methodology - the past, the present, and the future", Total Quality Management \& Business Excellence, Vol. 24 Nos 11-12, pp. 1241-1252.

Woodham, O.P., Williams, J.A. and McNeil, K.R. (2017), "Toward Understanding the Impact of Attributes on Satisfaction in Different Price Tiers." Journal of Consumer Satisfaction, Dissatisfaction and Complaining Behavior, Vol. 29, p.28.

Woodhouse, D. (2006), "Quality = fitness for purpose", paper presented at the APQN, Shanghai.

Xu, Q., Jiao, R.J., Yang, X., and Helander, M. (2009), “An analytical Kano model for customer need analysis", Design Studies Vol. 30 No. 1 pp. 87-110.

Yeh, T.M. (2010), "Determining medical service improvement priority by integrating the refined Kano model, quality function deployment and fuzzy integrals", African Journal of Business Management, Vol. 4 No. 12, pp. 2534-2545.

Zemsky, R. (2009), Making reform work: The case for transforming American higher education. Piscataway, NJ: Rutgers University Press. 
Table 3. Sunder (2016) Questionnaire

\section{APPENDIX}

\begin{tabular}{|c|c|c|c|c|c|c|}
\hline \multirow{2}{*}{$\begin{array}{c}\text { Stakeholder Expectation ("WHAT") } \\
\text { How do you feel if... }\end{array}$} & \multirow[b]{2}{*}{\begin{tabular}{|c|} 
Importance 9-point Likert \\
scale (1=Never Important; \\
2=Not very Important; \\
3=Occasionally Important; \\
4=Sometimes Important; \\
5=Fairly many times Important; \\
6=Quite often Important; \\
7=Very often Important; \\
8=Continually Important; \\
9=Always Important.
\end{tabular}} & \multicolumn{5}{|c|}{ Choose either (1), (2), (3), (4) or (5) only } \\
\hline & & \begin{tabular}{|l|} 
I like it \\
that \\
way \\
\\
\end{tabular} & \begin{tabular}{|l|} 
It must \\
be that \\
way
\end{tabular} & $\begin{array}{l}I \text { am } \\
\text { neutral }\end{array}$ & $\begin{array}{l}\text { I can } \\
\text { live } \\
\text { with it } \\
\text { that } \\
\text { way }\end{array}$ & $\begin{array}{l}\text { I dislike } \\
\text { it that } \\
\text { way }\end{array}$ \\
\hline 1a. Pass percentage of students in a class is high & & (1) & (2) & (3) & (4) & (5) \\
\hline 1b. Pass percentage of students in a class is not high & & (1) & (2) & (3) & (4) & (5) \\
\hline 2a.Turnaround time for issuing books in the library is high & & (1) & (2) & (3) & (4) & (5) \\
\hline $2 \mathrm{~b}$. Turnaround time for issuing books in the library is not high & & (1) & (2) & (3) & (4) & (5) \\
\hline 3a. Turnaround time for admission process is high & & (1) & (2) & (3) & (4) & (5) \\
\hline 3b. Turnaround time for admission process is not high & & (1) & (2) & (3) & (4) & (5) \\
\hline 4a. Overall student satisfaction score is high & & (1) & (2) & (3) & (4) & (5) \\
\hline 4b. Overall student satisfaction score is not high & & (1) & (2) & (3) & (4) & (5) \\
\hline 5a. Computer Laboratory equipment availability is high. & & (1) & (2) & (3) & (4) & (5) \\
\hline 5b. Computer Laboratory equipment availability is not high. & & (1) & (2) & (3) & (4) & (5) \\
\hline 6a. Computer systems downtime at the university is high & & (1) & (2) & (3) & (4) & (5) \\
\hline 6b. Computer systems downtime at the university is not high & & (1) & (2) & (3) & (4) & (5) \\
\hline 7a. Number of students placed at corporate jobs is high & & (1) & (2) & (3) & (4) & (5) \\
\hline 7b. Number of students placed at corporate jobs is not high & & (1) & (2) & (3) & (4) & (5) \\
\hline 8a. Salary range of passed students from the University is high & & (1) & (2) & (3) & (4) & (5) \\
\hline 8 b. Salary range of passed students from the University is not high & & (1) & (2) & (3) & (4) & (5) \\
\hline 9a. Residential facilities at hostel rooms is high & & (1) & (2) & (3) & (4) & (5) \\
\hline 9b. Residential facilities at hostel rooms is not high & & (1) & (2) & (3) & (4) & (5) \\
\hline 10a. There are facilities for gymnasium and sports center & & (1) & (2) & (3) & (4) & (5) \\
\hline 10b. There are no facilities for gymnasium and sports center & & (1) & (2) & (3) & (4) & (5) \\
\hline 11a. There are increase in students' enrollment; & & (1) & (2) & (3) & (4) & (5) \\
\hline 11b. There are no increase in students' enrollment; & & (1) & (2) & (3) & (4) & (5) \\
\hline 12a. There is an improvement in university ranking; & & (1) & (2) & (3) & (4) & (5) \\
\hline $12 \mathrm{~b}$. There is no improvement in university ranking; & & (1) & (2) & (3) & (4) & (5) \\
\hline 13a. There is an increase in research papers published per department; & & (1) & (2) & (3) & (4) & (5) \\
\hline $13 \mathrm{~b}$. There is no increase in research papers published per department; & & (1) & (2) & (3) & (4) & (5) \\
\hline 14a. Quality of research is high; & & (1) & (2) & (3) & (4) & (5) \\
\hline 14b. Quality of research is not high; & & (1) & (2) & (3) & (4) & (5) \\
\hline 15a.University maintenance culture is high; & & (1) & (2) & (3) & (4) & (5) \\
\hline 15b. University maintenance culture is not high; & & (1) & (2) & (3) & (4) & (5) \\
\hline 16a. Food wastage in University cafeteria is high & & (1) & (2) & (3) & (4) & (5) \\
\hline 16b. Food wastage in University cafeteria is not high & & (1) & (2) & (3) & (4) & (5) \\
\hline 17a. Standard of teaching is high; & & (1) & (2) & (3) & (4) & (5) \\
\hline $17 \mathrm{~b}$. Standard of teaching is not high; & & (1) & (2) & (3) & (4) & (5) \\
\hline 18a. Student's absenteeism is high; & & (1) & (2) & (3) & (4) & (5) \\
\hline 18b. Student's absenteeism is not high; & & (1) & (2) & (3) & (4) & (5) \\
\hline 19a. Accuracy of medical prescriptions at University's clinic is high; & & (1) & (2) & (3) & (4) & (5) \\
\hline 19b. Accuracy of medical prescriptions at University's clinic is high; & & (1) & (2) & (3) & (4) & (5) \\
\hline 20a. Paper consumption in the university is high; & & (1) & (2) & (3) & (4) & (5) \\
\hline 20b. Paper consumption in the university is not high; & & (1) & (2) & (3) & (4) & (5) \\
\hline 21a. Accreditation process is efficient; & & (1) & (2) & (3) & (4) & (5) \\
\hline 21b. Accreditation process is not efficient; & & (1) & (2) & (3) & (4) & (5) \\
\hline 22a. Accreditation would ensure quality; & & (1) & (2) & (3) & (4) & (5) \\
\hline 22b. Accreditation would not ensure quality; & & (1) & (2) & (3) & (4) & (5) \\
\hline
\end{tabular}

